\title{
Respiration of wood ant nest material affected by material and forest stand characteristics
}

\author{
Veronika Jilkova $^{1,2}$, Timo Domisch ${ }^{3,4}$, Zuzana HorickA ${ }^{1,2} \&$ Jan Frouz $^{1,2}$ \\ ${ }^{1}$ Institute of Soil Biology, AS CR, Na Sadkach 7, CZ-37005 Ceske Budejovice, Czech Republic; \\ e-mail: jilkova.veronika@gmail.com \\ ${ }^{2}$ Institute for Environmental Studies, Charles University in Prague, Benatska 2, CZ-12800 Praha, Czech Republic \\ ${ }^{3}$ Faculty of Forestry, University of Joensuu, P.O. Box 111, FI-80101 Joensuu, Finland \\ ${ }^{4}$ Finnish Forest Research Institute, Joensuu Research Unit, P.O. Box 68, FI-80101 Joensuu, Finland
}

\begin{abstract}
We studied differences in respiration of materials from different parts of wood ant nest (top, bottom, and rim) and from the nest surroundings (humus layer and mineral soil). Samples were taken from 8 wood ant (Formica aquilonia) nests in each of the two types of forest (birch and pine) in eastern Finland. The differences were related to material and forest stand characteristics (i.e., moisture, $\mathrm{pH}$, carbon content, and $\mathrm{C}: \mathrm{N}$ ratio). As a result, the highest respiration per $\mathrm{g}$ DW was measured at the top of ant nests in the birch forest. However, respiration did not significantly differ between the parts of ant nests in the pine forest. Respiration of the humus layers in both forest stands was on average higher, whereas respiration of the mineral soils in both forest stands was lower in comparison with respiration of the nest materials. The respiration per g C did not show any significant differences between different parts of nests and surrounding soil. The most important factors influencing respiration of the materials appeared to be moisture, carbon content, and $\mathrm{pH}$. In conclusion, respiration of wood ant nest material is affected by the specific material and forest stand characteristics.
\end{abstract}

Key words: Formica aquilonia; birch forest; pine forest; $\mathrm{CO}_{2}$; moisture; carbon content; pH

\section{Introduction}

Wood ants (Formica s. str., Hymenoptera: Formicidae) include species of ants that are dominant in temperate and boreal forest ecosystems (Dlusskij 1967). They are widespread from the temperate zone of Europe and Asia to the North-Palaearctic area, even north of the Arctic Circle (Czechowski et al. 2002; Punttila \& Kilpeläinen 2009). Wood ant species are mainly associated with coniferous and mixed forests, although they occur also in deciduous forests (Czechowski et al. 2002).

Due to their foraging and building activities they affect especially nutrient cycling (Frouz et al. 2005; Frouz \& Jílková 2008). Recently, their nests were found to be "hot spots" for $\mathrm{CO}_{2}$ production (Ohashi et al. 2005; Risch et al. 2005; Domisch et al. 2006). This $\mathrm{CO}_{2}$ originates from several sources: ant respiration, decomposer community respiration, and respiration of roots penetrating into the belowground parts of the nest (Lenoir et al. 2001; Risch et al. 2005). In our study, we focused on the decomposition activity of organisms (i.e., $\mathrm{CO}_{2}$ efflux), which is an important part of the carbon cycle (Steubing 1970). The knowledge of $\mathrm{CO}_{2}$ sources and their dependence on environmental characteristics is important to the understanding of ecosystem carbon balance in forest ecosystems.

Respiration of the decomposer community can be influenced by many material properties, such as mois- ture, acidity, carbon content, $\mathrm{C}: \mathrm{N}$ ratio, or the relation between cellulose and lignin (Edwards et al. 1970; Steubing 1970; Paul \& Clark 1996). Although the ant nest material is reported to be drier in comparison to the nest surroundings, decomposition processes are rather favoured there (Frouz et al. 1997; Laakso \& Setälä 1997; Lafleur et al. 2002). Since the water content differs between the parts of the nest, the moisture is highest in the upper part of the nest where there was also measured the highest temperature (Coenen-Staß et al. 1980). Thus, microbial activity and decomposition processes are encouraged especially in moist surface layers of ant nests (Laakso \& Setälä 1998; Dauber et al. 2001; Frouz et al. 2003). Wood ant nests and their close vicinity are usually reported to be less acidic in comparison with the wider surroundings (Jílková et al. 2011, 2012), which could also favour the activity of bacteria and actinomycetes, not only fungi typical for acidic soils (Paul \& Clark 1996). Because of foraging and building activities of ants, amount of organic matter (i.e. carbon content) is enhanced in ant nests (Frouz et al. 1997), but the quality of organic matter $(\mathrm{C}: \mathrm{N}$ ratio and the relation between cellulose and lignin) depends on the source of organic matter and thus on the forest stand (Edwards et al. 1970).

In this study we examined material respiration in different parts of ant nests in two forest stands and in the humus layer and mineral soil from the surroundings 
Table 1. Properties of materials from the respective sampling locations at the birch and the pine forest.

\begin{tabular}{|c|c|c|c|c|}
\hline \multirow[t]{2}{*}{$\begin{array}{l}\text { Sampling } \\
\text { location }\end{array}$} & $\begin{array}{c}\text { Moisture }(\%) \\
\mathrm{F}_{(4,56)}=5.04 P<0.05\end{array}$ & $\begin{array}{c}\mathrm{pH} \\
\mathrm{F}_{(4,56)}=6.16 P<0.001 \\
\end{array}$ & $\begin{array}{c}\text { Carbon content }(\%) \\
\mathrm{F}_{(4,56)}=6.79 P<0.001\end{array}$ & $\begin{array}{c}\text { C:N ratio } \\
\mathrm{F}_{(4,56)}=15.76 P<0.001\end{array}$ \\
\hline & Birch & Birch & Birch & Birch \\
\hline TOP & 5 a 19 & $4 \mathrm{a} 4.50$ & a 5 & \\
\hline ВОТТОМ & $22.50 \pm 1.43 \mathrm{~b} 16.80 \pm 1.33 \mathrm{w}$ & $5.23 \pm 0.08 \mathrm{a} 5.19 \pm 0$ & $32.58 \pm 0.88 \mathrm{~b} 25.40 \pm 5.44 \mathrm{x}$ & $19.22 \pm 0.78 \mathrm{a} 30.27 \pm$ \\
\hline RIM & $21.80 \pm 5.00 \mathrm{~b} 11.46 \pm 1.22 \mathrm{w}$ & $5.24 \pm 0.07 \mathrm{a} \quad 4.86 \pm 0.06 \mathrm{y}$ & $12.07 \pm 4.14 \mathrm{c} \quad 9.14 \pm 0.26 \mathrm{y}$ & $19.05 \pm 0.42 \mathrm{a} 30.12 \pm 0.15 \mathrm{x}$ \\
\hline HUMUS & $59.01 \pm 2.18 \mathrm{c} \quad 51.19 \pm 4.97 \mathrm{x}$ & $3.97 \pm 0.07 \mathrm{~b} 3.73 \pm 0.07 \mathrm{z}$ & $45.44 \pm 1.01 \mathrm{a} 29.74 \pm 2.55 \mathrm{x}$ & $22.50 \pm 0.80 \mathrm{a} 31.23 \pm 0.35 \mathrm{x}$ \\
\hline SOIL & $16.15 \pm 1.82 \mathrm{~b} 20.00 \pm 0.75 \mathrm{w}$ & $4.81 \pm 0.12 \mathrm{a} 5.18 \pm 0.03 \mathrm{x}$ & $0.63 \pm 0.03 \mathrm{~d} \quad 2.23 \pm 0.16 \mathrm{y}$ & $30.78 \pm 3.08 \mathrm{~b} 36.07 \pm 1.46 \mathrm{x}$ \\
\hline
\end{tabular}

Explanations: TOP refers to the top of the ant nests, BOTTOM to the base of the nests, RIM to the periphery of the nests, and HUMUS and SOIL to the humus layer and mineral soil, respectively, as controls. Mean \pm SEM and results of three-way ANOVAs are shown. Statistically homogeneous groups of values of the same material property are marked by the same letter (one-way ANOVA, Tukey HSD post hoc test).

as controls. We related the differences to microsite and forest stand characteristics. Our hypotheses were that (1) material respiration is the highest in the top of the nests, (2) the differences in material respiration are explained by material properties (e.g., moisture, $\mathrm{pH}$, carbon content), and (3) the forest stand characteristics are responsible for the differences in material respiration, especially due to carbon content of the litter.

\section{Material and methods}

Study sites

The study was conducted in August 2009 in two forest stands, birch (Betula pendula Roth) and pine (Pinus sylvestris L.), in eastern Finland near Joensuu $\left(62^{\circ} 39^{\prime} 28^{\prime \prime} \mathrm{N}\right.$, $29^{\circ} 39^{\prime} 38^{\prime \prime} \mathrm{E}$, birch stand; $62^{\circ} 41^{\prime} 20^{\prime \prime} \mathrm{N}, 29^{\circ} 44^{\prime} 33^{\prime \prime} \mathrm{E}$, pine stand). The birch forest was a 47 -year old stand with a tree density of 2,376 trees per ha and an ant nest density of 9.9 nests per ha. Ant nests in the birch forest were constructed mainly from birch twigs, bark, and leaves. However, a small portion of the pine needle material was also included since the birch forest stand was situated ca. $100 \mathrm{~m}$ from the pine forest stand. The pine forest was a 37-year old stand with a tree density of 2,235 trees per ha and an ant nest density of 6.3 nests per ha. Ant nests in the pine forest were constructed mainly from pine twigs and needles, with a considerable amount of conifer resin.

\section{Sampling design}

Samples of materials were taken with a shovel from 8 mounds of Formica aquilonia Yarrow, 1955 ants in both forest stands. Sampling locations were the top $(20 \mathrm{~cm}$ below the surface), the bottom (the centre of the mounds on the level of the forest floor) and the soil rim of the mounds (the periphery of the mounds), and the humus layer and mineral soil approximately $10 \mathrm{~m}$ from an adjacent mound as controls. In total, 80 material samples were taken. Fresh samples were immediately transported to the laboratory for analyses.

\section{Material analyses}

Respiration of the materials, moisture, $\mathrm{pH}$, and content of carbon and nitrogen were measured. Respiration was established using $5 \mathrm{~g}$ of the fresh materials after a two-day incubation at $20^{\circ} \mathrm{C}$ by titration of $\mathrm{NaOH}$ according to Page (1982). Moisture was determined as a difference between fresh mass and dry mass after drying at $105^{\circ} \mathrm{C}$ for $12 \mathrm{~h}$. $\mathrm{pH}$ was measured in a 1:10 material: water suspension with a glass electrode. The organic matter content was assessed based on loss-on-ignition after $5 \mathrm{~h}$ in $600{ }^{\circ} \mathrm{C}$. The content of carbon and nitrogen was analyzed in samples of dry crushed soil using elemental analyzer EA 1108 (Carlo Erba Instruments).

\section{Statistical analyses}

Three-way ANOVA with forest stand, sampling location and nest as categorical variables, with nest as a random effect nested in forest stand, were used to analyze differences in material properties. If the interaction between forest stand and sampling location was significant, one-way ANOVA and post hoc test (Tukey HSD) was performed to assess differences between the sampling locations. All computations were made using the program Statistica 10.

\section{Results}

Material respiration per g DW soil differed significantly between the sampling locations and forest stands (Fig. 1). Differences were more pronounced in the birch forest than in the pine forest. The highest respiration was measured at the top of ant nests in the birch forest, where it was seven times higher than respiration at the top of ant nests in the pine forest. The bottom and rim in both forest stands, as well as the top of ant nests in the pine forest were not markedly different in material respiration. Respiration of the humus layers in both forest stands was significantly higher than respiration of mineral soils; it was also higher than respiration at the bottom and rim of ant nests in both forest stands, whereas respiration of the mineral soils was lower. When we calculated respiration per $\mathrm{g} \mathrm{C}$, the differences between individual parts of nests and nest surroundings were not significant.

The other material properties also considerably differed between the two forest stands (Table 1). Ant nests in the birch forest were on average moister than ant nests in the pine forest with the highest moisture at the top of ant nests. Material pH was similar in both forest stands and was lower at the tops of ant nests in comparison with the bottoms and rims. The carbon content was the highest at the tops of ant nests in both forest stands with greater differences between sampling locations in the pine forest. $\mathrm{C}: \mathrm{N}$ ratio was on average higher in the pine forest with the highest value at the 


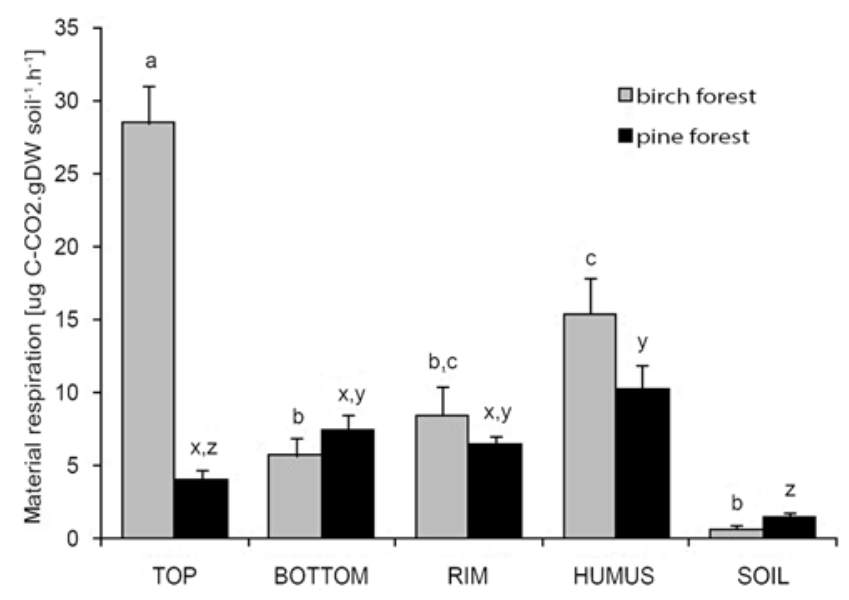

Fig. 1. Respiration of materials per g DW soil from sampling locations in the birch and pine forests (three-way ANOVA, F 4,56 $=22.35, P<0.001)$. TOP refers to the top of the ant nests, BOTTOM to the base of the nests, RIM to the periphery of the nests, and HUMUS and SOIL to the humus layer and mineral soil, respectively, as controls. Columns with different letters are statistically different (one-way ANOVA, Tukey HSD post hoc test). Means \pm SEM are shown.

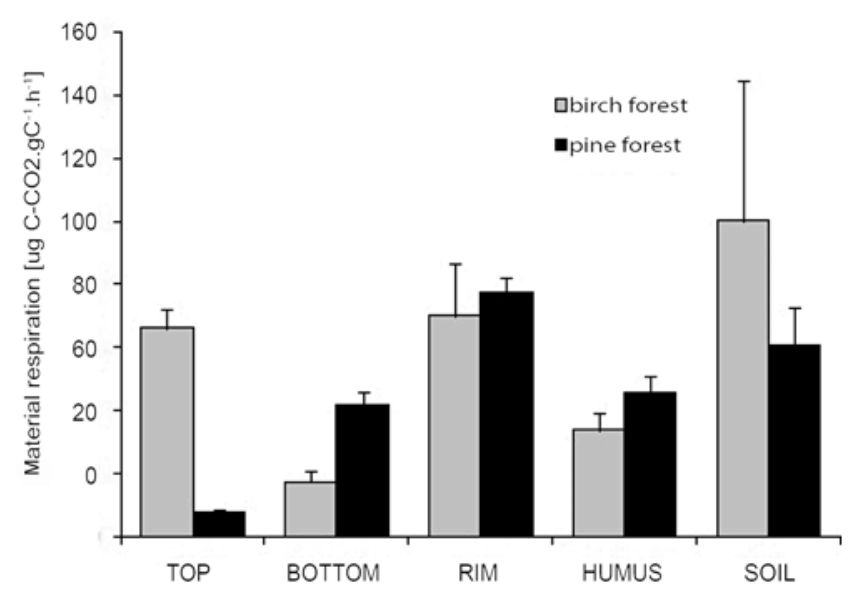

Fig. 2. Respiration of materials per g carbon from sampling locations in the birch and pine forests (three-way ANOVA, F 4,56 $=1.42, P=0.24)$. TOP refers to the top of the ant nests, BOTTOM to the base of the nests, RIM to the periphery of the nests, and HUMUS and SOIL to the humus layer and mineral soil, respectively, as controls. Means \pm SEM are shown.

top of ant nests. In the birch forest, $\mathrm{C}: \mathrm{N}$ ratio did not differ between the sampling locations.

\section{Discussion}

In agreement with our hypotheses, material respiration per g DW differed between the sampling locations and, also, between the two forest stands. This confirms earlier findings that the same species can affect soil properties differently in different ecosystems (Frouz et al. 2003; Holec \& Frouz 2006). Respiration of the material from the top of ant nests in the birch forest was significantly higher than respiration in the other parts of ant nests. Since litter decomposition is a complex process dependent on moisture, temperature, or litter quality (Edwards et al. 1970; Steubing 1970; Paul \& Clark 1996), this significant difference could be most probably explained by higher moisture of the material from the top of ant nests together with quite low $\mathrm{C}: \mathrm{N}$ ratio in the birch forest in comparison with the pine forest. However, in the pine forest the respiration of the nest materials from the different parts of ant nests was similar. The reason for missing significant differences between microsites within ant nests could be similar moisture in all the materials and $\mathrm{C}: \mathrm{N}$ ratio in the material from the top twice as high as in the bottom and rim of ant nests. Despite the low $\mathrm{pH}$ of the humus layers in both forest stands, the humus layer respiration was higher than in the bottoms and rims of ant nests, which could be caused by higher moisture and carbon content. Apparently, the moisture, $\mathrm{C}: \mathrm{N}$ ratio, and carbon content, separately or in combination, had an important effect on material respiration in our samples.

Even though the temperature is considered to be the most important factor influencing the rate of organic matter turnover, its overall effect is complicated by the interaction between temperature and moisture (Edwards et al. 1970). In addition to higher temperatures recorded inside ant mounds (Coenen-Staß et al. 1980), an increase of moisture was found stimulating decomposition processes of mound material (Frouz 1996; Lenoir et al. 2001). But as mounds are usually drier than the surrounding forest floor due to ant constructing activities (Seifert 1996; Lafleur et al. 2002), decomposition processes can be lowered there (Lenoir et al. 2001; Domisch et al. 2008). Nevertheless, decomposition in ant nests in the pine forest was not decreased due to lower moisture content, which suggests that there are other properties affecting this process, e.g. carbon availability. On the other hand, materials from ant nests in the birch forest had on average higher moisture than in the pine forest, which means that the litter decomposition was promoted there probably due to higher moisture content. This result is in accordance with results of Coenen-Staß et al. (1980), who found higher moisture inside ant nests, and thus increased microbial activity.

Nevertheless, the material respiration was affected not only by moisture, but also by the $\mathrm{C}: \mathrm{N}$ ratio, which was found to be lower in the birch forest and thus to be another factor stimulating decomposition in this forest stand. $\mathrm{C}: \mathrm{N}$ ratio at the top of ant nests in the pine forest was twice as high in comparison with the bottom and the rim. Mound material at the top of ant nests in the pine forest consists predominantly of needles, whereas the bottom and the rim consist of the mixture of needles and mineral soil (Kristiansen \& Amelung 2001). Needles from coniferous trees contain resistant constituents such as cellulose and lignin, and often have large $\mathrm{C}: \mathrm{N}$ ratio (Steubing 1970). Hence, the $\mathrm{C}: \mathrm{N}$ ratio at the top of ant nests in the pine forest was affected by the high $\mathrm{C}: \mathrm{N}$ ratio of needles.

However, since the availability of carbon is very important for the respiration of organisms (Schulze et al. 2000), we calculated the respiration per g C and 
it showed different results than the respiration per $g$ DW. The respiration increased in ant nests, especially in comparison to the humus layers. The most important properties that probably affected the respiration were $\mathrm{pH}$ of the material and availability of carbon. Higher $\mathrm{pH}$ favors the activity of bacteria more than that of fungi (Paul \& Clark 1996). Since bacteria have higher rate of metabolism, it can thus lead to higher $\mathrm{CO}_{2}$ production. In ant nests, ants accumulate vast amounts of food, mainly honeydew, which consists of simple sugars easily available to microorganisms. Microorganisms have enough energy for decomposition processes and that also leads to higher $\mathrm{CO}_{2}$ production (i.e., priming effect).

In conclusion, our data showed that material decomposition, and thus $\mathrm{CO}_{2}$ efflux, in our forest stands are affected mainly by moisture, carbon content and availability, $\mathrm{C}: \mathrm{N}$ ratio, and $\mathrm{pH}$. Although we examined ant mounds of the same species (Formica aquilonia) in both forest stands, material properties of ant nests differed between the birch and the pine forests. From this we can conclude that nest material properties are affected not only by the ant species present and its way of life, feeding and nest construction (Petal 1978), but also by the forest stand characteristics.

\section{Acknowledgements}

The authors thank to the University in Joensuu and the Finnish Forest Research Institute for providing the laboratory equipment. The study was financially supported by the grant MEYS CR (No LC06066).

\section{References}

Coenen-Staß D. 1980. Temperature distribution and calorimetric determination of heat production in the nest of the wood ant, Formica polyctena (Hymenoptera, Formicidae). Ecology 61 (2): 238-244. http://dx.doi.org/10.2307/1935180

Czechowski W., Radchenko A. \& Czechowska W. 2002. The Ants (Hymenoptera, Formicidae) of Poland. Museum and Institute of Zoology PAS, Warszawa, 200 pp. ISBN: 838519298

Dauber J., Schroeter D. \& Wolters V. 2001. Species specific effects of ants on microbial activity and N-availability in the soil of an old-field. In: Eur. J. Soil Biol. 37 (4): 259-261. DOI: 10.1016/S1164-5563(01)01094-9

Dlusskij G.M. 1967. Muravji roda Formica. Nauka, Moskva, 235 pp.

Domisch T., Finér L., Ohashi M., Risch A.C., Sundström L., Niemelä P. \& Jürgensen M.F. 2006. Contribution of red wood ant mounds to forest floor $\mathrm{CO}_{2}$ efflux in boreal coniferous forests. Soil Biol. Biochem. 38 (8): 2425-2433. DOI: 10.1016/j.soilbio.2006.03.004

Domisch T., Ohashi M., Finér L., Risch A.C., Sundström L., Kilpeläinen J. \& Niemelä P. 2008. Decomposition of organic matter and nutrient mineralisation in wood ant (Formica rufa group) mounds in boreal coniferous forests of different age. Biol. Fert. Soils 44 (3): 539-545. DOI: 10.1007/s00374-0070248-0

Edwards C.A., Reichle D.E. \& Crossley D.A. 1970. The role of soil invertebrates in turnover of organic matter and nutrients, pp. 147-172. In: Reichle D.E. (ed.), Analysis of Temperate Forest Ecosystems. Series title: Ecological Studies 1, Springer Verlag, Berlin, 304 pp. ISBN: 354004793X / ISBN13: 9783540047933
Frouz J. 1996. The role of nest moisture in thermoregulation of ant (Formica polyctena, Hymenoptera, Formicidae) nests. Biologia 51 (5): 541-547.

Frouz J., Holec M. \& Kalčík J. 2003. The effect of Lasius niger (Hymenoptera, Formicidae) ant nest on selected soil chemical properties. Pedobiologia 47 (3): 205-212. DOI: 10.1078/0031-4056-00184

Frouz J. \& Jílková V. 2008. The effect of ants on soil properties and processes (Hymenoptera: Formicidae). Myrmecological News 1: 191-199.

Frouz J., Kalčík J. \& Cudlín P. 2005. Accumulation of phosphorus in nests of red wood ants Formica s. str. Ann. Zool. Fen. 42 (3): 269-275.

Frouz J., Šantrůčková H. \& Kalčík J. 1997. The effect of wood ants (Formica polyctena Foerst.) on the transformation of phosphorus in a spruce plantation. Pedobiologia 41 (5): 437447.

Holec M. \& Frouz J. 2006. The effect of two ant species Lasius niger and Lasius flavus on soil properties in two contrasting habitats. Eur. J. Soil Biol. 42 (Suppl. 1): S213-S217. DOI: 10.1016/j.ejsobi.2006.07.033

Jílková V., Matějíček L. \& Frouz J. 2011. Changes in the pH and other soil chemical parameters in soil surrounding wood ant (Formica polyctena) nests. Eur. J. Soil Biol. 47 (1): $72-$ 76. DOI: $10.1016 /$ j.ejsobi.2010.10.0

Jílková V., Šebek M. \& Frouz J. 2012. Mechanisms of pH change in wood ant (Formica polyctena) nests. Pedobiologia 55 (5): 247-251. DOI: 10.1016/j.pedobi.2012.04.002

Kristiansen S.M. \& Amelung W. 2001. Abandoned anthills of Formica polyctena and soil heterogeneity in a temperate deciduous forest: morphology and organic matter composition. Eur. J. Soil Sci. 52 (3): 355-363. DOI: 10.1046/j.13652389.2001.00390.x

Laakso J. \& Setälä H. 1997. Nest mounds of red wood ants (Formica aquilonia): hot spots for litter-dwelling earthworms. Oecologia 111 (4): 565-569. DOI: 10.1007/s004420050272

Laakso J. \& Setälä H. 1998. Composition and trophic structure of detrital food web in ant nest mounds of Formica aquilonia and in the surrounding forest soil. Oikos 81 (2): 266-278. DOI: $10.2307 / 3547047$

Lafleur B., Bradley R.L. \& Francoeur A. 2002. Soil modification created by ants along a post-fire chronosequence in lichenspruce woodland. Ecoscience 9 (1): 63-73.

Lenoir L., Persson T. \& Bengtsson J. 2001. Wood ant nests as potential hot spots for carbon and nitrogen mineralisation. Biol. Fert. Soils 34 (4): 235-240. DOI: 10.1007/s003740100405

Ohashi M., Finér L., Domisch T., Risch A.C. \& Jürgensen M.F. 2005. $\mathrm{CO}_{2}$ efflux from red wood ant mound in a boreal forest. Agr. Forest Meteorol. 130 (1-2): 131-136. DOI: $10.1016 /$ j.agrformet.2005.03.002

Page A.L. 1982. Methods of Soil Analysis. Part 2. Chemical and Microbiological Properties. American Society of Agronomy, 1159 pp. ISBN: 0-89118-072-9

Paul E.A. \& Clark F.E. 1996. Soil Microbiology and Biochemistry. $2^{\text {nd }}$ Ed. Academic Press, San Diego, 340 pp. ISBN: 012-546806-7.

Petal J. 1978. The role of ants in ecosystems, pp. 293-325. In: Brian M.V. (ed.), Production Ecology of Ants and Termites, International Biological Programme 13, Cambridge University Press, Cambridge, 409 pp. ISBN: 0-521-21519-6

Punttila P. \& Kilpeläinen J. 2009. Distribution of moundbuilding ant species (Formica spp., Hymenoptera) in Finland: preliminary results of a national survey. Ann. Zool. Fenn. 46 (1): 1-15.

Risch A.C., Jürgensen M.F., Page-Dumroese D.S. \& Schütz M. 2005. The contribution of red wood ants to soil $\mathrm{C}$ and $\mathrm{N}$ pools and $\mathrm{CO}_{2}$ emissions in subalpine forests. Ecology 86 (2): 419430. DOI: $10.1890 / 04-0159$

Schulze E.-D., Högberg P., van Oene H., Persson T., Harrison A.F., Read D., Kjöller A. \& Matteucci G. 2000. Interactions between the carbon and nitrogen cycle and the role of biodiversity: A synopsis of study along a north-south transect through Europe. Part E: Integration, Chapter 21, pp. 468492. In: Schulze, E.-D. (ed.), Carbon and Nitrogen Cycling 
in European Forest Ecosystems, Ecol. Studies 142, Springer Verlag, Berlin, 509 pp. ISBN: 3-540-67025-4

Seifert B. 1996. Ameisen: beobachten, bestimmen. Naturbuch Verlag, Ausburg, 352 pp. ISBN: 3-89440-170-2
Steubing L. 1970. Soil flora: Studies of the number and activity of microorganisms in woodland soils, pp. 131-146. In: Reichle D.E. (ed.), Analysis of Temperate Forest Ecosystems, Ecological Studies 1, Springer Verlag, Berlin, 304 pp. ISBN: 354004793X / ISBN-13: 9783540047933

Received October 11, 2012 Accepted August 16, 2013 